\title{
Citra Partai Keadilan Sejahtera Mengenai Perubahan Lambang Partai bagi Generasi Muda
}

\author{
Vera Wijayanti Sutjipto, Maulina Larasati Putri, Marisa Puspita Sary, Fahira Novanra, \\ Putri Dwi Rizni Ananda. \\ Ilmu Komunikasi, Fakultas Ilmu Sosial, Universitas Negeri Jakarta \\ E-mail: verawijayanti@unj.ac.id
}

DOI: https://doi.org/10.21107/ilkom.v15i2.11986

\begin{abstract}
ABSTRAK
PKS kembali meluncurkan simbol partai barunya. Perubahan ini bukan kali pertama yang dilakukan oleh PKS. Perubahan lambang yang dilakukan dalam hal ini bertujuan untuk mendapatkan suara di kalangan generasi muda pada pemilu mendatang. Perubahan terakhir pada lambang PKS terletak pada bentuknya yang bulat dengan kombinasi warna oranye yang berarti kehangatan dan putih yang melambangkan ketulusan. Inti dari perubahan simbol ini adalah agar PKS tampil lebih segar, lebih dekat dan terbuka dengan berbagai kalangan, termasuk generasi muda. Untuk itu, penelitian ini ingin mengetahui bagaimana citra PKS terhadap perubahan simbol partai bagi generasi muda. Penelitian ini menggunakan pendekatan kuantitatif dengan jenis penelitian yang digunakan adalah deskriptif. Penelitian ini memiliki satu variabel yaitu citra perubahan simbol. Metode pengumpulan data dilakukan dengan menyebarkan kuesioner kepada 102 responden sesuai dengan kriteria penelitian yaitu generasi muda yang berusia antara 17 tahun sampai dengan 25 tahun. Hasil penelitian ini menunjukan bahwa generasi muda mengetahui tentang perubahan simbol PKS melalui media sosial. Lambang baru PKS berwarna jingga ini, dinilai lebih segar dari lambang sebelumnya yang didominasi warna hitam sehingga terkesan kuno dan monoton. Perubahan lambang PKS berhasil mengubah citra positif partai bagi generasi muda. Generasi mdua beranggapan bahwa perubahan lambang menjadi salah satu upaya yang dilakukan PKS dalam melibatkan dan mewadahi aspirasi generasi muda di dunia politik kedepannya. Lambang baru PKS yang lebih sederhana dan fresh, lebih mudah dipahami generasi muda dan berhasil menciptakan citra opitimisme dan semagnat PKS dalam politik kedepannya. Generasi muda juga menilai tampilan baru PKS menampilkan visi dan misi partai dengan lebih jelas dan mudah dipahami generasi muda. Namun perubahan ini belum cukup untuk membuat generasi muda memilih PKS pada pemilu mendatang. Bagi generasi muda, perubahan lambang harus diimabngi dengan peningkatan kinerja partai.
\end{abstract}

Kata Kunci: Citra, Partai, Simbol, Generasi Muda

\section{ABSTRACT}

PKS re-launched its new party symbol. The change of symbol is not only carried out by PKS this time, the change of symbol this time is one of $P K S^{\prime}$ strategies to win votes among the younger generation in the upcoming elections. The last change in the PKS symbol lies in its round shape with a combination of orange which means warmth and white which represents sincerity. The essence of this symbol change is to make PKS appear fresher, closer and open to various groups, including the younger generation. For this reason,

Cite this as :

Sutcipto, Vera W., Maulina L.P., Marisa P.S., Fahira N., Putri D.R.A. (2021). Citra Partai Keadilan Sejahtera Mengenai Perubahan Lambang Partai bagi Generasi Muda. Jurnal Komunikasi, 15(2), 157-168. doi: https://doi.org/10.21107/ilkom.v15i2.11986
Article History :

Received August, $17^{\text {th }}$ 2021,

Acepted September, $7^{\text {th }} 2021$

(C) 2021 Author (s) 
this study wanted to find out how the image of PKS towards changes in party symbols for the younger generation. This study uses a quantitative approach with the type of research used is descriptive. This study has one variable, namely the image of the symbol changes. The method of data collection was carried out by distributing questionnaires to 102 respondents according to the research criteria, namely the younger generation aged between 17 years to 25 years. The results of this study, most respondents know about the change in the PKS symbol through social media. The new orange PKS symbol is considered fresher than the previous black symbol, so that the majority of the younger generation expressed interest in the new PKS symbol. In addition, the younger generation considers the new PKS symbol to be pleasing to the eye, in contrast to the old symbol which seems ancient. The new PKS emblem reflects the PKS work strategy and the party's vision and mission. The latest PKS symbol is easy to remember and consider simple. other than that it still shows the personality of the party in accordance with Islamic ideology and the behavior of party members.

Keywords: Image, Party, Symbol, Youth.

\section{PENDAHULUAN}

Kegagalan ataupun kesuksesan organisasi bisa terjadi akibat peran pemimpin dalam mengelola organisasinya. Mengutip dalam Wahab (2015: 3) kepemimpinan menjadi salah satu faktor untuk mengubah dan mengembangkan sebuah organisasi. Beberapa kasus kegagalan pemimpin telah mencuat ke permukaan, diberitakan oleh BBC News Indonesia (2017) bahwa terdapat 2 pimpinan Pertamina yang dicopot jabatannya karena tidak bisa bekerja sama. Menteri Badan Usaha Miik Negara, Rini Soemarno memutuskan mencopot jabatan pimpinan Pertamina yaitu Direktur Utama Dwi Soetjipto dan Wakil Direktur Utama Ahmad Bambang.

Partai Keadilan Sejahtera atau yang lebih dikenal dengan PKS didirikan pada tanggal 20 Juli 1998 dengannama awal Partai Keadilan yang dipimpin oleh Nurmahmudi Ismail pada saat konferensi pers di Aula Masjid Al-Azhar, Kebayoran Baru, Jakarta (Sejarah Ringkas, 2011). Sejak Awal berdiri, partai ini sudah banyak melakukan perubahan terutama pada bentuk lambang partai.

Pada acara Musyawarah Nasional V PKS di Bandung, Partai Keadilan Sejahtera Kembali meluncurkan lambang, mars, dan hymne baru yang dimana sudah direncanakan pada kepengurusan sebelumnya. Perubahan Lambang terbaru PKS terletak pada bentuknya yang bulat dengan perpaduan warna oranye dan putih yang sebelumnya memiliki lambang berbentukpersegi dengan warna hitam-emas namun, unsur bulan sabit dan padi tetap menjadi ciri khas dari partai politik ini (Farisa, 2020). Rocky Gerung selaku pengamat politik menjelaskan bahwa simbol atau lambang baru dari PKS dinilai lebih segar dan membuktikan bahwa PKS terus berevolusi (Subhanie, 2020).

Setiap organisasi yang mengubah identitas tentu memiliki alasan dan tujuan tertentu, begitupun dengan perubahan lambang pada Partai Keadilan Sejahtera yang kini dominan berwarna oranye yang bermakna kehangatan dan semangat muda serta warna putih yang mendeskripsikan ketulusan dan kesucian hati(Saputro, 2020). Menurut Aboe Bakar Alhabsy selaku Sekretaris Jendral PKS menjelaskan bahwa hakikat dari adanya perubahan ini agar PKS tampil lebih segar, lebih dekat dan terbuka dengan berbagai kalangan termasuk generasi muda (Putri, 2020). Menurut pandangan Kunto Adi Wibowo selaku pengamat politik, langkah PKS mengubah lambang menunjukkaniktikad parpol tersebut menarik suara generasi muda jelang Pemilu 2024 ("Pengamat: PKS Ubah Lambang untuk Bidik Suara Milenial," 2020). Kepala BPS Suhariyanto, pun juga menjelaskan bahwa Indonesia saat ini masih mengalami bonus demografi karena jumlah penduduk usia produktif mengalami peningkatan (Idris, 2021)

Jika dilihat dari hasil sensus penduduk September 2020 jumlah usia produktif (15-64 
tahun) adalah 70,72\% yang menandakan bahwa Indonesia masih dalam masa bonus demografi, dengan dominasi Generasi Z (8-23 tahun) sebesar 27,94\%, Generasi Milenial (24-39 tahun) sebesar 25,87\% diposisi kedua dan generasi X (40-66 tahun) sebesar 21,88\% diposisi ketiga (Hasil Sensus Penduduk 2020, 2020). Kesempatan emas dengan banyaknya generasi muda saat ini tentu membuat PKS melakukan rebrending untuk menampilkan citra yang baik dimata masyarakat usia muda seperti yang dikatakan Netty Prasetiyani selaku Ketua DPP Partai Keadilan Sejahtera (PKS) bahwa memang tujuan perubahan lambang partainya untuk memikat pemilih dari kelompok milenial dan perempuan (Maharani, 2020).

Namun rebrending memakan waktu yang lama karena terkait faktor internal, misalnya para kader PKS harus memperkenalkan kembali lambang baru ke masyarakat dan juga faktor eksternal dari masyarakat itu sendiri dalam menilai perubahan lambang tersebut. PKS, maka dari itu penelitian ini dilakukan dengan tujuan untuk mengetahui bagaimana citra PKS setelah lambang partai berubah di mata generasi muda. Apakah perubahan lambang mengubah citra dari PKS sebagai partai yang lebih dekat dengan generasi muda sehingga mereka tertarik untuk memilik PKS pada pemilu dimasa mendatang.

Sebelumnya terdapat beberapa artikel penelitian terdahulu yang memiliki varibel yang sama. Artikel pertama yang ditulis oleh Ben Isa Muhammad (2021) dengan judul Makna Perubahan Lambang Partai Keadilan Sejahtera (PKS) dan Hubungannya dengan Brand Image PKS. Pendekatan yang di gunakan pada penelitian ini adalah pendekatan kualitatif dengan metode analisis semiotika Charles Sanders Peirce. Berdasarkan hasil dari penelitian tersebut menunjukan bahwa makna yang direpresentasikan dalam visual lambang baru PKS adalah perubahan citra partai dari yang lebih agamis dan formal menjadi lebih netral, muda, dan dinamis. Perbuahan lambang PKS dinilai sebagai bentuk evolusi PKS. Dengan bentuk desain yang lebih modern yang adaptif dan organic. Perubahan Lambang PKS tersebut dianggap sebagai bagian dari corporate rebranding dan merupakan strategi partai untuk menarik minat kalangan milenial (Muhammad, 2021). Dalam hal ini, penelitian akan dikembangkan oleh peneliti kali ini dengan fokus masalah pada bagaimana citra partai keadilan sejahtera terkait perubahan lambang partai bagi generasi muda dengan pendekatan yang berbeda yaitu menggunakan mendekatan kuantitatif

Artikel kedua ditulis oleh Nila Sastrawati (2015) dengan judul Simbolisme dalam pencitraan partai politik. Berdasarkan hasil penelitian ini, diketahui bahwa simbol dan politik yang merupakan dua hal berbeda namun tidak dapat di pisahkan. Dengan memiliki makna simbol yang baik maka akan menampilkan citra yang luar biasa sehingga mampu menjadi pemikat dalam mewujudkan tujuan partai politik. Pada penelitian ini menjelaskan makna simbolik dari setiap simbol objek visual, baik dari segi warna, gambar, dan desain garis (Sastrawati, 2015). Dengan begitu yang akan dikembangkan oleh peneliti kali ini adalah melihat citra partai politik PKS terkait lambang baru partai sebagai simbol objek visual partai politik bagi generasi muda.

Pada penelitian ini, perubahan lambang PKS dilakukan dengan tujuan untuk meningkat citra politik partai, sehingga PKS tampil lebih segar, lebih dekat dan terbuka dengan berbagai kalangan termasuk generasi muda. Menurut (Yulianto, 2014), Citra politik sendiri terdiri dari 3 aspek, yaitu Aspek kognisi, afeksi dan juga konasi.

1) Aspek Kognisi merupakan aspek yang terkait dengan penyampaian wawasan yang benar maupun keliru yang harus dikelola secara fair dan seimbang.

2) Aspek afeksi merupakan aspek yang mampu memberikan hal yang melekat dan bisa menarik perasaan publik.

3) Aspek konasi merupakan aspek yang terkait dengan pengharapan yang dimiliki 
orang tentang apa yang mungkin terjadi seperti sebuah perubahan yang semakin mensejahterakan masyarakat.

Lambang partai merupakan elemen identitas yang sangat penting. Lambang berfungsi untuk mewakili ruang lingkup kerja, mencerminkan visi dan misi, serta untuk menampilkan budaya (Oscario, 2013). Adapun ciri Lambang yang baik untuk meningkatkan branding menurut (Oscario, 2013) antara lain adalah:

1) Berperan sebagai kepribadian entitas yang diwakilinya

2) Memiliki ciri khas dan keunikan dari competitor,

3) Simpel dan fleksibel sehingga mudah untuk diingat dengan

\section{METODE PENELITIAN}

Pada penelitian ini menggunakan pendekatan kuantitatif, dimana analisis datanya berbentuk numerik/angka yang bertujuan untuk menggembangkan model matematis, teori dan juga hipotesis yang berkaitandengan kasus yang disedang diteliti (Suryani, 2016). Jenis penelitian yang digunakan adalah deskriptif. Tujuan dari penelitian deskriptif untuk membuat deskripsi secarasistematis, faktual dan akurat mengenai fakta-fakta serta hubungan dari fenomena yang sedang di teliti (Rukajat, 2018).

Penelitian ini menggambarkan citra PKS dimata generasi muda setelah adanya perubahan lambang partai. Metode pengumpulan data yang dilakukan dengan menyebarkan kuesioner kepada 100 responden yangsesuai dengan kriteria penelitian yaitu generasi muda yang berusia antara 17 tahun sampai dengan 25 tahun.

Untuk menguji validnya suatu variabel dalam penelitian ini, maka penulis menggunakan uji Kaiser Meyer-Olkin (KMO). Varibel dinyatakan valid dan bisa dianalisis lebih lanjut apabila angka KMO harus $\geq 0,5$ dan tingkat probabilitas (sig) harus lebih $\leq 0,05$ (Natanael, 2013).

Tabel. 1 Hasil Uji Validitas

\begin{tabular}{|c|c|c|}
\hline \multicolumn{3}{|c|}{ KMO and Bartlett's Test } \\
\hline \multicolumn{2}{|c|}{$\begin{array}{c}\text { Kaiser-Meyer-Olkin Measure } \\
\text { of } \\
\text { Sampling Adequacy. }\end{array}$} & .889 \\
\hline \multirow{3}{*}{$\begin{array}{l}\text { Bartlett's Test } \\
\text { of Sphericity }\end{array}$} & $\begin{array}{c}\text { Approx. } \\
\text { Chi-Square }\end{array}$ & 3316.809 \\
\hline & Df & 630 \\
\hline & Sig. & .000 \\
\hline
\end{tabular}

Berdasarkan data pada Tabel 1. Hasil Uji validitas variabel menunjukan nilai KMO sebesar 0.889 dengan nilai Sig. 0.000. Dari data tersebut diketahui bahwa nilai uji KMO $\geq 0.5$ dan nilai Significant (Sig.) $\leq 0,05$ sehinggadata dinyatakan valid.

Tabel. 2 Hasil Uji Reabilitas

\begin{tabular}{|c|c|}
\hline \multicolumn{2}{|c|}{ Reliability Statistics } \\
\hline Cronbach's Alpha & N of Items \\
\hline .955 & 36 \\
\hline
\end{tabular}

Dalam pengujian Realibilitas dilakukan denganmenganalisis nilai croncbach's alpha dalam data statistik. Instrumen dari data penelitian dapat dikatakan reliabel dengan syarat, nilai croncbach alpha $\geq 0,6$ (Gumilar, 2010). Berdasarkan tabel 2 dapat diketahui bahwa nilai Cronbach's Alpha dalam penilaian ini sebesar $0,955 \geq 0,6$ sehingga bisa disimpulkan bahwa variabel ini memiliki nilai yang reliabel.

Pada penelitian ini, terdapat satu variabel penelitian yaitu citra perubahan lambang dengan tiga dimensi, antara lain adalah aspek citra, fungsi lambang dan ciri lambang. Variabel penelitian ini diturunkan 
ke dalam beberapa dimensi dan indikator di dalam tabel operasional konsep sehingga lebih rinci dan dapat diukur.

Tabel. 3 Operasional Konsep

\begin{tabular}{|c|c|c|c|}
\hline Variabel & Dimensi & Indikator & Skala \\
\hline \multirow{9}{*}{$\begin{array}{l}\text { Citra } \\
\text { Perubahan } \\
\text { Lambang }\end{array}$} & \multirow{3}{*}{$\begin{array}{l}\text { Aspek } \\
\text { Citra }\end{array}$} & Kognisi & \multirow{9}{*}{ Interval } \\
\hline & & Afeksi & \\
\hline & & Konasi & \\
\hline & \multirow{3}{*}{$\begin{array}{l}\text { Ciri } \\
\text { Lambang }\end{array}$} & $\begin{array}{l}\text { Menunjukan } \\
\text { kepribadian } \\
\text { entitas yang } \\
\text { diwakilinya }\end{array}$ & \\
\hline & & $\begin{array}{l}\text { Memiliki ciri } \\
\text { khasdan } \\
\text { keunikan } \\
\text { dari } \\
\text { competitor }\end{array}$ & \\
\hline & & $\begin{array}{l}\text { Simple dan } \\
\text { fleksibel }\end{array}$ & \\
\hline & \multirow{3}{*}{$\begin{array}{l}\text { Fungsi } \\
\text { Lambang }\end{array}$} & $\begin{array}{l}\text { Mewakili } \\
\text { ruanglingkup } \\
\text { kerja }\end{array}$ & \\
\hline & & $\begin{array}{l}\text { Mencerminka } \\
\text { nvisi dan misi }\end{array}$ & \\
\hline & & $\begin{array}{l}\text { Mencerminaka } \\
\text { n budaya }\end{array}$ & \\
\hline
\end{tabular}

\section{HASIL DAN PEMBAHASAN}

Lambang adalah elemen visual yang dapat membentuk citra dan identitas suatu organisasi. Lambang atau logo merupakan simbol khas organisasi, objek, ide atau layanan dimana harus mudah untuk di identifikasi. Untuk mengetahui citra perubahan lambangPKS bagi generasi muda maka peneliti mendapatkan hasil kuioner yang telah diisi oleh 102 responden. Berikut merupakan informasi umum dari responden penelitian ini. Pada penelitian ini jumlah responden yang mengisikuesioner sebanyak 102 orang. Rentang usia mereka antara 17 tahun sampai 22 tahun. Mayoritas berusia 20 tahun yaitu sebanyak 42 orang, sedangkan respondendengan usia 17 tahun hanya ada 2 orang. Sebagianbesar responden adalah mahasiswa dari berbagaiperguruan tinggi di Jabotabek, hanya 4 orang yang masih duduk di SMA.

Sebanyak 72 orang menyatakan bahwa mereka bukanlah simpatisan PKS, hanya 30 orang yang menyatakan diri sebagai simpatisan PKS, disamping itu sebagian besar juga menyatakan bahwa mereka bukan kader PKS yaitu 89 orang, sekitar 13 orang yang menyatakan mereka adalah kader PKS. Responden yang memilih PKS pada Pemilu 2019 yang lalu hanya 38 orang sedangkan sebagian besar yaitu 64 orang tidak memilih PKS.

Berikut adalah pembahasan terkait dimensi pertama yaitu aspek citra.

Tabel. 4 Dimensi Aspek Citra

\begin{tabular}{|c|l|l|l|l|l|}
\hline $\begin{array}{c}\text { Ind } \\
\cdot\end{array}$ & Pernyataan & F.Max & F.Min & Ratarata & $\begin{array}{c}\text { Ket } \\
\cdot\end{array}$ \\
\hline Kognisi & A & 48 & 10 & 2.80 & V \\
\hline Afeksi & B & 50 & 11 & 2.61 & V \\
\hline Konasi & $\mathrm{C}$ & 62 & 7 & 2.85 & V \\
\hline
\end{tabular}

\section{Keterangan:}

$\mathrm{A}=$ Mengetahui perubahan lambang PKS

$\mathrm{B}=$ Tertarik dengan lambang baru PKS

$\mathrm{C}=$ Menampilkn citra positif baru

$\mathrm{V}=$ Setuju

Dimensi aspek citra mempunyai tiga indikator yaitu kognisi, afeksi dan konasi. Pada aspek kognisi ada 3 (tiga) pernyataan yaitu mengetahui perubahan lambang, mudah mengingat lambang baru PKS dan tertarik menggali wawasan lebih mengenai partai PKS. berdasarkan tabel diatas, maka dapat disimpulkan bahwa sebagian besar responden mengetahui adanya perubahan lambang PKS, dimana nilai rata-rata 2.80 yang menujukan setuju dengan pernyataan ini. Hal tersebut juga dilihat dari frekuensi tertinggi yaitu 48 responden yang menyatakan setuju bahwa mereka mengetahui perubahan lambang PKS dan frekuensi terendah 10 responden yang 
menyatakan tidak tidak mengetahui adanya perubahan lambang PKS tersebut. Salah satu responden yang menyatakan tidak mengetahui perubahan lambang melalui media sosial, seperti pernyataan dibawah ini

\begin{abstract}
"Iya tau, waktu itu ada tugas mengenai komunikasi politik, trus mencoba mancari politisi PKS melaluiInstagram, pas dilihat dari postingan beliau, ternyata terlihat lambang PKS sudah berubah" - Mutiara
\end{abstract}

Pada aspek afeksi juga terdapat 3 (tiga) pernyataan yaitu tertarik dengan lambang, menyukai lambang dan dapat menerima lambang baru PKS. Berdasarkan tabeldiatas, maka dapat disimpulkan bahwa sebagian besar responden tertarik dengan lambang baru PKS. Hal tersebut dapat dilihat dari nilai rata-rata 2,61 yangmenunjukan keterangan setuju dengan pernyataan ini.Selain itu juga dapat dilihat dari frekuensi tertinggi 42 responden yang menyatakan setuju bahwa merekatertarik dengan lambang baru PKS dan frekuensi terendah nya 12 responden yang menyatakan tidak tertarik dengan lambang baru PKS. Sebagian dariresponden tertarik dengan lambang baru PKS. Hal ini dikarenakan responden menilai bahwa lambang baru PKS terlihat lebih segar di banding lambang sebelumnya.

"Keren kok, kalau dilihat-lihat lebih terlihat fresh aja gituh dibanding sebelumnya" - Mutiara

Pada aspek konasi juga terdapat 3 (tiga) pernyataan yaitu merubah pandangan, menampilkan citra positif baru dan memberikan harapan baru terhadap masa depan partai. Berdasarkan tabel diatas, maka dapat disimpulkan bahwa sebagian besar responden berpendapat bahwa perubahan lambang PKS mampu manampilkan citra positif baru PKS. Hal tersebut dapat dilihat dari nilairata-rata 2,85 yang menunjukan keterangan setujudengan pernyataan ini. Selain itu juga dapat dilihat dari frekuensi tertinggi 62 responden yang menyatakan setujubahwa lambang baru PKS menampilkan citra positif baru dan frekuensi terendahnya 7 responden yang menyatakan tidak setuju dengan perrnyataan tersebut.

Menurut salah satu responden, perubahan lambang berhasil mengubah pandangannya terhadap partai. Ia berpendapat bahwa lambang PKS yang sebelumnya dianggap terlihat kuno. Maka dengan adanya perubahan lambang ini, membuat pemnbaharuan pada pertain sehingga dipandang lebih baik dan citra yang ditampilkan lebih positif.

"Tadinya mengiranya kalau PKS itu
kuno, tapi ternyata dengan adanya
perubahan lambang ini membuat saya
berfikir tenyata PKS mampu berevolusi
dan menyesuaikan jaman juga" - Kiki

Selanjutnya merupakan pembahasan terkait dimensi kedua yaitu fungsi lambang

Tabel. 5 Dimensi Fungsi Lambang

\begin{tabular}{|l|c|c|c|l|l|}
\hline \multicolumn{1}{|c|}{$\begin{array}{c}\text { Ind } \\
\cdot\end{array}$} & $\begin{array}{c}\text { Pernya } \\
\text { taan }\end{array}$ & F.Max & F.Min & Ratarata & $\begin{array}{c}\text { Ket } \\
\cdot\end{array}$ \\
\hline Area Kerja & A & 55 & 10 & 2.79 & V \\
\hline Visi \& misi & B & 67 & 7 & 2.82 & V \\
\hline Budaya & C & 60 & 4 & $2.85=1$ & V \\
\hline
\end{tabular}

\section{Keterangan:}

$\mathrm{A}=$ Mencerminkan strategi kerja partai

$\mathrm{B}=$ Mencerminkan visi dan misi

$\mathrm{C}=$ Sesuai dengan budaya organisasi partai PKS

$\mathrm{V}=$ Setuju

Dalam dimensi fungsi lambang memiliki tiga indikator yaitu mewakili area atau ruang lingkup kerja, mencerminkan visi dan misi, dan mencerminkan budaya. Pada fungsi mewakili ruang lingkup kerja terdapat 3 (tiga) pernyataan yaitu mencerminkan sistem kerja partai, mencerminkan srategi kerja partai, dan mencerminkan budaya kerjayang baru bagi generasi muda partai.

Berdasarkan tabel diatas, maka dapat disimpulkan bahwa sebagian besar responden berpendapat lambang baru PKS mencerminkan strategi kerja partai. Hal 
tersebutdapat dilihat dari nilai rata-rata 2,79 yang menunjukan keterangan setuju dengan pernyataan ini. Selain itu juga dapat dilihat dari frekuensi tertinggi 55 responden yang menyatakan setuju bahwa lambang baru PKS mencerminkan strategi kerja partai dan frekuensi terendah nya 7 responden yang menyatakan tidak setuju dengan perrnyataan tersebut. Dari data temuan tersebut, dapat diketahui bahwa perubahan lambang PKS dinilai sebagai strategi PKS untuk memperlihatkan kinerja partai kedepannya. Salah satu responden berpendapat bahwa perubahan lambang baru PKS ini terlihat sebagai perubahan strategi kerja PKS kedepannya yang dirasa akan lebih akrab dengan generasi muda. Sehingga responden merasa generasi muda akan dilibatkan dalam berbagai kinerja partai guna mencapai visi misi partai dan mendapatkanide-ide baru dan lebihkreatif.

\begin{abstract}
"Terlihat sih, mungkin strategi kerja partai nya inginlebih dekat dengan generasi muda, sehingga mudah mendapatkan ide ide baru dan kreatif" -
\end{abstract} febrizka

Pada fungsi mencerminkan visi dan misi terdapat 5 (lima) pernyataan yaitu mencerminkan visi, misi, tujuan partai, masa depan partai, dan langkah positif partai. Berdasarkan tabel diatas, maka dapat disimpulkanbahwa sebagian besar responden berpendapat lambang baru PKS mencerminkan visi dan misi partai sesuai dengan nilai rata-rata 2.82 yang menujukan keterngan setuju dengan pernyataan ini. Hal tersebut juga dapat dilihat dari frekuensi tertinggi 67 responden yang menyatakan setuju bahwa lambang baru PKS mencerminkan visi dan misi partai dan frekuensi terendah 7 responden menyatakan sangat tidak setuju mengenai pernyataan tersebut. Salah seorang responden mengatakan bahwa setiap makna dalam elemen di lambang baru PKS mencerminkan visi dan misi partai. Menurutnya, lambang baru PKS lebih jelasdalam menampilkan visi misi nya dimana mencerminkan visi partai yang mewadahi setiap suara masyrakat tak terkecuali generasi muda serta melibatkan generasi mudadalam berpolitik.

\begin{abstract}
"Kalau kita lihat dari makna tiap elemen yang ada di lambang baru PKS, Itu mencerminkan visi misipartai sih kalau menurut saya" - Kiki
\end{abstract}

Pada fungsi mencerminkan budaya terdapat 2 (dua) pernyataan yaitu sesuai dengan ideologi PKS dan budaya organisasi PKS. Berdasarkan tabel diatas, maka dapat disimpulkan bahwa sebagian besar responden berpendapat lambang baru PKS sesuai dengan budaya organisasi partai PKS. Hal tersebut dapat dilihat dari nilai rata-rata 2.81 yang menujukan keterangan setuju dengan pernyataan ini. Hal tersebut juga dapat dilihat dari frekuensi tertinggi 60 responden yang menyatakan setujubahwa lambang baru PKS sesuai dengan budaya organisasi partai PKS dan frekuensi terendah 4 responden yang menyatakan sangat tidak setuju mengenai pernyataan tersebut. Salah satu responden berpendapat bahwa lambang PKS yang baru dirasa lebihmencerminkan budaya partai. Ia menilai bahwa budaya yang ditampilkan adalah budaya optimism partai yaitu sebuah semangat untuk mencapai tujuan partai. Pemilihan warna dari lambang partai dinilai sebagai cerminan budaya partai yang hangat baik dengan organisasi internal maupun dengan masyrakat.

"Menurut saya, terlihat sih budaya PKS
ingin dekat dan hangat ke semua
kalangan serta optimisan partai
menggapai tujuan partai nya" - Febrizka

Berikutnya merupakan pembahasan dimensi ketiga mengenai ciri lambang

Tabel. 6 Dimensi Ciri Lambang

\begin{tabular}{|l|c|l|l|l|l|}
\hline \multicolumn{1}{|c|}{$\begin{array}{c}\text { Ind } \\
\cdot\end{array}$} & $\begin{array}{c}\text { Pernya } \\
\text { taan }\end{array}$ & F.Max & F.Min & Ratarata & $\begin{array}{c}\text { Ket } \\
\cdot\end{array}$ \\
\hline Kepribadian & $\mathrm{A}$ & 55 & 9 & 2.80 & $\mathrm{~V}$ \\
\hline Ciri Khas & $\mathrm{B}$ & 60 & 4 & 2.98 & $\mathrm{~V}$ \\
\hline \multirow{2}{*}{ Simple } & $\mathrm{C}$ & 59 & 3 & 2.96 & $\mathrm{~V}$ \\
\cline { 2 - 6 } & $\mathrm{D}$ & 61 & 4 & 3.02 & $\mathrm{~V}$ \\
\hline
\end{tabular}

\section{Keterangan:}

$\mathrm{A}=$ Mencerminkan strategi kerja partai

$\mathrm{B}=$ Mencerminkan visi dan misi

$\mathrm{C}=$ Sesuai dengan budaya organisasi partai PKS

$\mathrm{V}=$ Setuju 
Dimensi ciri lambang mempunyai tiga indikator yaitu menunjukan kepribadian entitas yang diwakilinya, memiliki ciri khas, serta simpel. Pada indikator menunjukan kepribadian PKS terdapat 2 (dua) pernyataan yaitu lambang PKS yang baru sesuai dengan ideologi islam dan sesuai dengan tingkah laku anggota partai.

Berdasarkan data temuan diatas, dapat diketahui bahwa indicator keperibadian mendapat nilai rata- rata 2.80.Dalam hal ini, 55 responden yang menyatakan setujubahwa lambang baru PKS sesuai dengan ideologi Islam dan frekuensi terendah 9 responden yang menyatakan tidak setuju bahwa lambang PKS yang baru sesuai dengan ideologi islam. Menurut responden, lambang baru dari PKS yang menunjukan gambar bulan sabit berhasil menampilkancitra partai Islamic. Responden menilai bahwa bulan sabit menampilkan keluhuran islam sehingga ideologi partai yang tergambar dari lambang dapat dipahami dengan mudah. Ia merasa ideologi partai yaitu islam dapat diketahui lebih mudah dalam lambang baru PKS. Berikut pernyatannya:

\footnotetext{
"Waktu saya mencari lebih dalam mengenailambang pks yang baru, sempet baca kalau salah satumakna bulan sabit itu melambangkan keluhuran Islam.Jadi dapat disimpulkan lambang baru PKS ini masih menunjukan ideologi islam partai" - Kiki
}

Pada indikator menunjukan ciri khas PKS terdapat 3 (tiga) pernyataan yaitu lambang PKS yang baru unik, berbeda dari partai lainnya, dan mencerminkan jati diri partai. Berdasarkan tabel diatas, maka dapat disimpulkanbahwa sebagian besar responden setuju bahwa lambangPKS yang baru berbeda dari partai lainnya, dimana nilai rata-rata 2.98 yang menunjukan setuju dengan pernyataan ini. Hal tersebut juga dilihat dari frekuensi tertinggi yaitu 60 responden yang menyatakan setujubahwa lambang baru PKS berbeda dari partai lainnya dan frekuensi terendah 4 responden yang menyatakan tidak setujubahwa lambang PKS yang baru berbeda dari partai lainnya. Dari data tersebut dapat diketahui bahwa rata rata responden beranggapan bahwa lambang baru PKS terlihat unik dan berbeda dengan partai lainnya hal ini dikarenakan warna partai orange yang mendominasi lambang.

"Lambang baru PKS ini unik sih soalnya
dibandingkan dengan partai yang
berideologi islamlainnya. Lambang partai
ini lebih mencolok warnanya"- Febrizka

Pada indikator simpel PKS terdapat 3 (tiga) pernyataan yaitu lambang PKS yang baru sederhana warnanya, gambarnya, serta mottonya. Berdasarkan tabel diatas, maka dapat disimpulkan bahwa sebagian besar responden setuju bahwa lambang PKS yang baru menggunakan warna yang lebih sederhana, dimana nilai rata-rata 2.96 yang menujukan setujudengan pernyataan ini. Hal tersebut juga dilihat dari frekuensi tertinggi yaitu 59 responden yang menyatakan setuju bahwa lambang baru PKS sederhana warnanya dan frekuensi terendah 3 responden yang menyatakan tidak setuju bahwa lambang PKS yang baru sederhana warnanya. Menurut salah satu responden, perpaduan warna orange pada lambang baru terlibah lebih sederhana dan serasi.

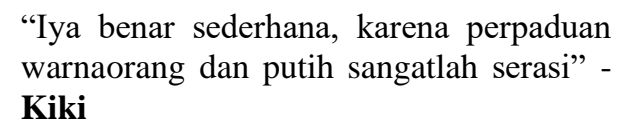

"Iya benar sederhana, karena perpaduan warnaorang dan putih sangatlah serasi" Kiki

Selain itu berdasarkan tabel diatas, maka dapat disimpulkan juga bahwa sebagian besar responden setuju bahwa lambang PKS yang baru sederhana gambarnya, dimana nilai rata-rata 3.02 yangmenujukan setuju dengan pernyataan ini. Hal tersebutjuga dilihat dari frekuensi tertinggi yaitu 61 responden yang menyatakan setuju bahwa lambang baru PKS sederhana gambarnya dan frekuensi terendah 4 responden yang menyatakan tidak setuju bahwa lambang PKS yang barusederhana gambarnya. Dalam hal ini, responden berpendapat bahwa lambang baru PKS yang menampilkan gambar padi dan dua bulan sabit terlihat lebih sederhana namun menarik.

\footnotetext{
"Simple sih, cuman padi yang dihimpit dua bulan sabit didalam lingkaran oranye" Febrizka
} 
Setelah membahas mengenai tiga dimensi tersebut maka dapat diketahui bahwa perubahan lambang tidak hanya kali ini dilakukan oleh PKS, berhasil memberi perubahan lambang merupakan salah satu strategi PKS untuk meraih suara di kalangan generasi muda pada pemilu yang akan datang. Kuesioner disebarkan pada kalangangenerasi muda dengan rentang usia 17 tahun sampai 25 tahun.

Mayoritas dari responden menyatakan bahwa mereka bukanlah kader PKS ataupun simpatisan PKS. Sebagian besar dari mereka, menyatakan bahwa pada pemilu yang lalu tidak memilih PKS. Kuesioner berisikan pernyataan-pernyatan yang terkait dengan citra lambang PKS, dimana ada tiga dimensiyang mempengaruhi citra tersebut yaitu dimensi aspek citra, dimensi fungsi lambang dan dimensi ciri lambang.

Pada dimensi aspek citra ada faktor kognitif, afektif dan konansi yang berpengaruh. Faktor kognitif merupakan pengetahuan generasi muda mengenai perubahan lambang PKS tersebut, mayoritas mereka mengetahui adanya perubahan lambang PKS tersebut, dalam rangka meraih suara lebih banyak pada pemilu yang akan datang. Mereka mengetahui perubahantersebut dari media sosial, mereka tertarik untuk mengaliinformasi lebih dalam lagi mengenai lambang baru PKS tersebut.

Faktor kedua adalah faktor afeksi. Afeksi merupakan perasaan generasai muda terhadap lambang baru PKStersebut, apakah disukai atau apakah mendapat respon positif. Mayoritas generasi muda menyatakan tertarik dengan lambang baru PKS, salah satu responden yairu generasi muda menyatakan bahwa lambang yang baru yang berwaranaoranye terlihat lebih fresh dibandingkan lambang sebelumnya yang berwarna hitam dan terlihat monoton.

Faktor ketiga adalah faktor konasi yaitu sikap dimana ada kecenderungan akan melakukan sesuatu yang terkait dengan sebuah objek. Mayoritas generasi muda berpendapat bahwa lambang PKS yang baru ternyata lebih menarik untuk dipandang. Responden berpendapat bahwa lambang baru jauh lebih menarik daripada lambang sebelumnya yang terkesan kuno, sehingga lambanga partai yang lama memberi kesan organisasinya kaku. Hal ini membuat generasi muda tidak tertarik dengan PKS. Akan tetapi dengan perubahan lambang yang dilakukan PKS berhasil memberikan pandangan baru bagi generasi muda. Generasi muda berpendapat bahwa PKS mampu berevolusi menyesuaikan diri dengan perkembangan zaman.

Dimensi kedua adalah dimensi fungsi lambang. Mayoritas generasi muda menyatakan bahwa lambang baru PKS mencerminkan strategi kerja dari PKS sebagaisebuah organisasi politik, dimana menurut salah seorangresponden, lambang baru PKS menunjukan usaha dari partai PKS yang lebih dekat dengan generasi muda. Upaya ini dinilai sebagaibentuk pendekatan PKS pada generasi muda untukmewadahi suara generasi muda dan melibatkan generasi muda dalam berpolitik kedepannya. Tidak hanya itu, lambang baru dari PKS juga menampilkan visi misi partai. Generasi muda merasa bahwa perubahan lambang ini telah mencerimakan visi misi partai yang lebih jelas kedepannya sehingga generasi muda dapat lebih memahami PKS dalam berpolitik pada masa mendatang.

Dimensi terakhir adalah dimensi ciri lambang. Pada dimensi ciri lambang, data temuan menunjukan bahwa menurut mayoritas generasi muda lambang PKS yang baru mewakili ideologi Islam, dimana adanya gambar bulan sabit yang merupakan ciri dari Islam, selain itulambang PKS yang sekarang lebih unik daripadalambang PKS sebelumnya. Bahkan lambang baru PKS yang menggunakan warna orange lebih menyala dinilai sebagai sebuah pembaharuan dan memberi kesan berbeda dengan partai politik lainnya yang biasanya menggunakan warna hitam atau hijau dalam melambangkan partai islam.

Menurut responden, lambang PKS yang baru telah mencerimakan system dan 
strategi kerja partai kedepannya. Tidak hanya itu, lambang baru dari PKS juga menunjukan budaya kerja baru dari partai yangdinilai lebih optimis dan pemih semangat muda. Lambang PKS yang baru ini juga telah mencerminkan visi, misi, tujuan, masa depan partai, serta langkah positif partai. Data menunjukan bahwa tampilan baru dari lampang PKS menunjukan secara jelas mengenai visi misi serta tujuan partai kedepannya yaitu menjadi partai politik yang terus berevolusi dan akan melibatkan generasi muda dalam kehidupan berpolitik. Usaha PKS untuk mengubah lambang partai dinilai sebagai upaya untuk mendekatkan partai dengan generasi mdua. Meskipun terdapat perubahan lambang partai, generasi muda berpendapat lambang tidak menghilangkan nilai ideologi PKS sebagai partai islam. Lambang PKS yang baru tetap menunjukan kepribadian partai sesuai dengan ideologi islam dan tingkah laku anggota partai.

Generasi menilai perubahan lambang PKS tidak hanya menunjukan bagaimana kinerja PKS kedepannya namun juga menjadi ciri khas PKS. Dengan tetap menunjukan jati diri partai sebagai partai islam, PKS terlihat memiliki identitas dan ciri khas yang jelas sesuai ideologi. Lambang baru PKS juga dianggap seabgai pembaharuan yang memudahkan generasi muda dalam mengenal, mengingat dan memahami PKS. Hal ini dikarekan pemilihan warna orange, gambar lingkaran, tipografi yang tegas sehingga mudah diingat dan terlihat lebih simple. Selain itu, warna yang lebih menyala juga menunjukan semangat muda yang terus dijunjung tinggi oleh PKS kedepannya.

\section{PENUTUP}

Perubahan lambang PKS merupakan salah satu strategi PKS membangun citra partai dalam rangka meraih suara pada pemilu yang akan datang, terutama pada kalangan generasi muda, dimana di prediksi pada Pemilu 2024 yang akan datang pemilih pemula berjumlah lebih dari separuh populasi pemilih.
Berdasarkan hasil penelitian diketahui bahwa perubahan lambang membawa dampak positif bagi citra partai PKS dimata generasi muda. Generasi muda menyukai lambang baru dari PKS ini. Mereka menilai bentuk dan warna lambang baru sangat berbeda dengan lambang lama dari partai yang terlihat kuno dan monoton sehingga generasi muda kurang tertarik untuk mengenal lebih jauh PKS. Akan tetapi, dengan perubahan yang dilakukan oleh PKS, generasi muda menilai PKS lebih fresh, penuh semangat muda, dan optimis.

Dengan perubahan lambang, PKS berhasil menunjukan visi misi partai dan usahanya untuk lebih dekat dengan generasi muda. Hal ini dikarenakan lambang partai mulai dari warna, tulisan hingga gambar yang mudah diingat, unik dan mudah dipahami.

Perubahan tidak hanya membawa citra positif partai namun juga membuat generasi muda semakin tertarik untuk mengenal PKS dengan mencari informasi lebih lanjut terkait PKS sehingga menambah wawasan politik dan pemahaman partai PKS.

Perubahan lambang ini juga merubah pandangan generasi muda terhadap PKS. Generasi muda menilai perubahan lambang memberi citra PKS yang akan melibatkan generasi muda dalam berpolitik kedepannya, generasi muda juga beranggapan bahwa perubahan lambang dapat menjadi langkah PKS untuk mewadahi aspirasi generasi muda kedepannya.

Meskipun telah berhasil meningkatkan citra partai, perubahan lambang PKS belum cukup dalam membuat generasi muda memilih PKS pada pemilu mendatang. Bagi generasi muda, perubahan lambang yang membawa citra positif harus diimbangi dengan perubahan positif baik internal maupun eksternal organisasi sehingga generasi muda dapat lebih yakin dalam memilih PKS pada pemilu mendatang. Adapun perubahan lain yang diperlukan seperti budaya partai yang mengutamakan hubungan baik antara pihak internal yaitu sesame anggota partai dengan pihak lain yaitu masyarakat. Budaya partai harus menunjung 
tinggi komunikasi yang baik, sikap yang positing dan nilai sosial lain yang sesuai dengan ideologi PKS sebagai partai islam.

Dengan perubahan tersebut, generasi mudaberpendapat bahwa hal tersebud dapat membetuk citra positinf yang lebih baik bagi partai sehingga tujuan untukmendapat suara di pemilu mendatang dapat semakin kuat dan kokoh dikalangan generasi muda.

\section{DAFTAR PUSTAKA}

Farisa, F. C. (2020). PKS Luncurkan Lambang Baru, Kini Berwarna Oranyedan Berbentuk Bulat. Kompas.Com.

https://nasional.kompas.com/read/ 2020/11/30/07272181/pksluncurkan-lambang-baru-kiniberwarna-oranye-dan-berbentukbulat?page $=$ all

Gumilar, I. (2010). Metode Riset Untuk Bisnis \&Manajemen. https://books.google.co.id/books?i $\underline{\mathrm{d}=\ln 8 \_ \text {EO TevsC }}$

Hasil Sensus Penduduk 2020. (2020).Bps.Go.Id. https://www.bps.go.id/

Idris, M. (2021). Generasi Z dan Milenial DominasiJumlah Penduduk Indonesia. Kompas.com https://money.kompas.com/read/20 21/01/22/14500\%201126/generasiz-dan-milenial-dominasi-jumlahpend\%20uduk-indonesia?page $=$ all

Maharani, T. (2020). Ketua DPP PKS: Logo Baru Diharapkan Pikat Milenial dan Perempuan. Kompas.Com.

Muhammad, B. I. (2021). Makna Perubahan Logo Partai Keadilan Sejahtera (Pks) Dan Hubungannya Dengan Brand
Image Pks. Jurnal Bahasa Rupa,4(2), 146-158. https://doi.org/10.31598/bahasarup a.v4i2.809

Natanael, S. Y. (2013). Mahir Menggunakan SPSS secara Otodidak. Elex Media Komputindo.

https://books.google.co.id/books?i $\mathrm{d}=\mathrm{h} 4 \mathrm{ZKDwAAQBAJ}$

Oscario, A. (2013). Pentingnya Peran Logo dalam Membangun Brand. Humaniora, 4(1), 191. https://doi.org/10.21512/humanior a.v4i1.3429

Pengamat: PKS Ubah Lambang untuk Bidik SuaraMilenial. (2020).CNN Indonesia.

https://www.cnnindonesia.com/nas ional/20201201195853-32576791/pengamat-pks-ubahlambang-untuk-bidik-suara$\underline{\text { milenial }}$

Putri, B. U. (2020). PKS Ganti Lambang Partai, Tak Lagi Pakai Unsur Ka'bah. Tempo.Co https://nasional.tempo.co/read/1409 941/pks-ganti-lambang-partai-taklagi-pakai-unsur-kabah

Rukajat, A. (2018). Pendekatan Penelitian Kualitatif. Deepublish.

Saputro, F. A. (2020). Ini Pengurus dan Lambang Baru PKS. https://republika.co.id/

Sastrawati, N. (2015). Simbolisme Dalam Pencitraan Partai Politik. Jurnal Al Daulah, 4.

Sejarah Ringkas. (2011).PKS.ID. https://pks.id/content/sejarahringkas 
Subhanie, D. (2020). PKS Punya Logo Baru, RockyGerung Bilang Begini. Sindonews.Com.

https://nasional.sindonews.com/rea d/256966/12/pks-punya-logo-barurocky-gerung-bilang-begini1607094756
Suryani, H. (2016). Metode Riset Kuantitatif: Teori dan Aplikasi pada Penelitian Bidang Manajemen dan Ekonomi Islam. Prenada Media.

Yulianto, A. (2014). Dinamika Komunikasi Politik dan Pembangunan di Era Demokrasi. Rajawali Pers 